\title{
8
}
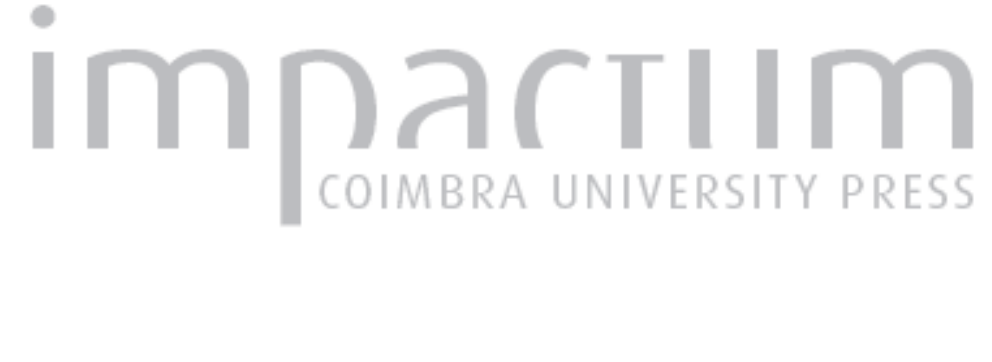

Comentário ao Liber de Causis de Santo Tomás de Aquino: tradução do Proêmio, das proposições I, II, III, VI, XV, XXI, XXXI e XXXII

\author{
Autor(es): $\quad$ Silveira, Carlos Frederico Gurgel Calvet da
}

Publicado por: $\begin{aligned} & \text { Universidade Católica de Petrópolis; Instituto Brasileiro de Informação } \\ & \text { em Ciência e Tecnologia }\end{aligned}$

URL

persistente:

URI:http://hdl.handle.net/10316.2/32991

DOI: $\quad$ DOI:http://dx.doi.org/10.14195/1984-6754_4-2_10

Accessed : $\quad$ 26-Apr-2023 14:23:28

A navegação consulta e descarregamento dos títulos inseridos nas Bibliotecas Digitais UC Digitalis, UC Pombalina e UC Impactum, pressupõem a aceitação plena e sem reservas dos Termos e Condições de Uso destas Bibliotecas Digitais, disponíveis em https://digitalis.uc.pt/pt-pt/termos.

Conforme exposto nos referidos Termos e Condições de Uso, o descarregamento de títulos de acesso restrito requer uma licença válida de autorização devendo o utilizador aceder ao(s) documento(s) a partir de um endereço de IP da instituição detentora da supramencionada licença.

Ao utilizador é apenas permitido o descarregamento para uso pessoal, pelo que o emprego do(s) título(s) descarregado(s) para outro fim, designadamente comercial, carece de autorização do respetivo autor ou editor da obra.

Na medida em que todas as obras da UC Digitalis se encontram protegidas pelo Código do Direito de Autor e Direitos Conexos e demais legislação aplicável, toda a cópia, parcial ou total, deste documento, nos casos em que é legalmente admitida, deverá conter ou fazer-se acompanhar por este aviso.

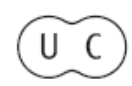



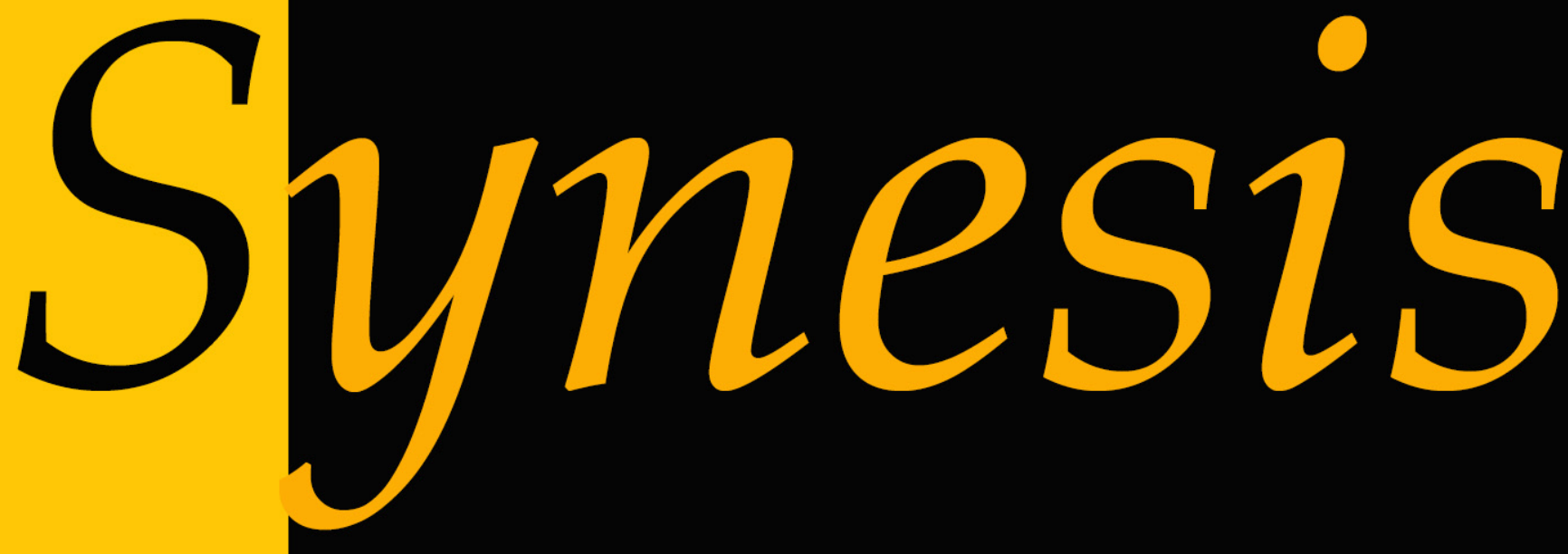

Revista do Centro de Teologia e Humanidades ISSN 1984-6754

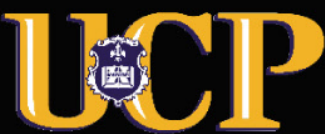


Comentário ao liber de Causis de santo tomás de AQUINO: TRADUÇÃo DO PROÊMIO, DAS ProposiçÕES I, II, III, VI, XV, XXI, XXXI E XXXII

\section{SAINT THOMAS AQUINAS' COMMENTARY ON THE LiBER DE CAUSIS: TRANSLATION OF PROEMIUM AND PROPOSITIONS I, II, III, VI, XV, XXI, XXXI AND XXXI"}

Carlos Frederico Gurgel Calvet da SiLvema* UNIVERSIDAde Cat́ólica de PETrópolis, BrasIL

Conspecto Geral da Obra

O Comentário ao Liber De Causis pertence à última fase das obras de Santo Tomás. Foi escrito, com toda segurança, no primeiro semestre de 1272, em Paris, como testemunha uma cópia parisiense da obra.

O De Causis trata das primeiras causas das coisas, que estão constituídas em três ordens, e da distinção e dependência das causas entre si. O texto de Santo Tomás segue passo a passo as proposições em que a obra se divide, que são trinta e duas. Estas trinta de duas proposições são verdadeiros capítulos desenvolvidos a partir de uma tese central. Santo Tomás expõem-nas a modo de lições. As proposições com seu conteúdo fundamental são as seguintes:

I. Proposição que ocupa o lugar de princípio de todo o tratado.

II. Os entes superiores pertencem a três graus, a saber: antes da eternidade, com a eternidade, depois da eternidade.

\footnotetext{
* Tradução recebida em 20/11/2012 e aprovada para publicação pelo Conselho Editorial em 30/11/2012.

* Doutor em Filosofia pela Pontificia Università San Tommaso (Roma). Professor Adjunto da Universidade Católica de Petrópolis. Currículo Lattes: http://lattes.cnpq.br/4874832664252533. E-mail: carlos.silveira@,ucp.br. 
III. De que modo a alma participa do Primeiro e do segundo.

IV. Como se distinguem os entes que pertencem ao primeiro grau intermediário, isto é, as inteligências.

V. A distinção do grau terceiro do ente, ou seja, das almas entre si, se depreende da distinção do grau do ente anterior (ou das inteligências).

VI. Declara por que motivo a causa primeira das coisas é inefável,

VII. A Inteligência quanto à sua substância.

VIII. Como a inteligência conhece aquilo que está acima dela e aquilo que está abaixo dela mesma.

IX. A inteligência recebe da causa primeira a virtude de governar e de conservar as coisas.

X. A inteligência conhece as coisas distintas de si mesma através das formas inteligíveis que possui em si.

XI. Como a inteligência se encontra diante das coisas sempiternas.

XII. Como se conhecem ou entendem mutuamente as inteligências que também são coisas sempiternas.

XIII. Como a inteligência consegue conhecer a si mesma e conhecer as coisas que estão nela mesma.

XIV. De que modo a alma contém em si as coisas sensíveis e inteligíveis.

XV. Como a alma conhece a si mesma.

XVI. Todas as virtudes não finitas dependem do primeiro infinito.

XVII. Por que entre muitas virtudes infinitas tem maior infinitude aquela que está mais próxima da unidade.

XVIII. Todas as coisas em sua natureza ou substância dependem do primeiro ente.

XIX. As coisas se assemelham ao primeiro dos seres segundo a participação de perfeição natural que cada uma delas recebe do primeiro ser.

$\mathrm{XX}$. De que modo a causa primeira exerce um governo universal, e como esse governo se distingue de qualquer outro.

XXI. O governo divino é suficiente pela abundância da bondade do mesmo.

XXII. O governo divino é suficiente pela excelência do mesmo.

XXIII. O regime da causa segunda.

XXIV. O regime divino é participado de diverso modo pelos diversos entes.

XXV. Todo aquele que subsiste por si não pode ser engendrado a partir de outra coisa. 
XXVI. Todo authypostaton, ou todo aquele que subsiste por si mesmo, é incorruptível.

XXVII. Condição da substância corruptível.

XXVIII. Toda substância subsistente por sua própria essência, é simples e corruptível.

XXIX. Toda substância simples é authypostaton ou subsistente por si mesma.

XXX. Como se relacionam entre si as substâncias que são medidas pelo tempo.

XXXI. Situação ou estado das substâncias cuja ação está no tempo e cuja substância está na eternidade.

XXXII. Outra condição ou maneira de ser da substância intermediária que existe sob outro aspecto ou está na eternidade.

Os temas acima dispostos em trinta e duas proposições são ordenados de modo estritamente metafísico por Santo Tomás, partindo, pois, dos princípios mais gerais a conclusões mais particulares. Consoante a edição de Ceslai Pera, OP ${ }^{1}$, as proposições estão ordenadas da forma que se segue.

I. O princípio para todo o tratado (I)

II. Sobre a Causa Primeira das coisas

a) a distinção das causas primeiras:

1. distinguem-se as Causas Primeiras (II-V)

2. determinam-se as causas singularmente (VI-XV)

b) a comparação das causas entre si:

1. a dependência dos inferiores em relação aos superiores (XVI-XIX)

2. o influxo dos superiores nos inferiores (XX-XXIII)

3. a recepção do influxo pelos inferiores (XXIV-XXXII)

1 A edição latina de base para esta tradução foi a seguinte: TOMÁS DE AQUINO. In Librum de Causis Expositio. Org.: fr. CESLAI PERA, o. p. Turim: Marietti, 1955. Foram ainda consultadas as edições: ID. Super Librum de Causis Expositio. Org.: H. D. SAFFREY, O. P. Paris: Jean Vrin, 2002; a tradução francesa: ID. Commentaire du Livre des Causis. Org.: Béatrice et Jérôme DÉCOSSAS. Paris: Jean Vrin, 2005; a espanhola: ID. Exposición sobre el "Libro de las Causas". Org.: Juan CRUZ CRUZ. Pamplona: EUNSA, 2000. 


\section{$\mathrm{PROENMIO}^{2}$}

Conforme o Filósofo no livro X da Ética, a felicidade última do homem consiste na melhor operação humana que é a sua suprema potência, ou seja, no intelecto em relação ao que é mais inteligível. E como o efeito se conhece pela causa, é claro que a causa por sua própria natureza é mais inteligível do que o efeito, embora às vezes os efeitos em relação a nós sejam mais conhecidos do que as causas, pois temos conhecimento das causas universais e inteligíveis através dos particulares que caem sob o nosso sentido.

Absolutamente falando, é necessário, pois, que as primeiras causas das coisas sejam em si mesmas máxima e otimamente inteligíveis, na mesma medida em que são maximamente entes e verdadeiras, e que são a causa da essência e da verdade dos outros entes, por mais que relativamente essas causas primeiras nos sejam menos conhecidas e posteriores. O nosso intelecto relaciona-se a elas como os olhos da coruja diante da luz do sol, que, por excesso de claridade, não a pode perceber.

Importa, pois, que a felicidade última que o homem pode alcançar nesta vida, consista na consideração das causas primeiras, porque, por menos que as possa conhecer, elas são mais amáveis e nobres do que todas as coisas inferiores que possa conhecer, como manifesta o Filósofo no I livro Sobre as partes dos animais.

Contudo, como esse conhecimento se plenifica após esta vida, o homem só então estará perfeitamente feliz, segundo o que diz o Evangelho: "Nisso consiste a vida eterna, que te conheçam verdadeiro Deus vivo". E daí que a primeira intenção dos filósofos era a de, por todas as coisas que consideravam, chegar ao conhecimento das causas primeiras. Donde colocassem por último a ciência das causas primeiras, cujo conhecimento dedicavam os últimos tempos de sua vida.

a) Primeiramente, iniciavam pela Lógica, que trata das regras das ciências;

b) Em segundo lugar, procediam com as Matemáticas, de que até as crianças são capazes;

c) Em terceiro, vinha a Filosofia Natural, que, em função da experiência, exige muito tempo;

d) Em quarto, a Filosofia Moral, que ao jovem não se mostra conveniente;

\footnotetext{
${ }^{2}$ Trata-se aqui de uma antologia da obra, especificamente do proêmio, das proposições I, II, III, VI, XV, XXI, XXXI e XXXII, conforme se indica no título. bttp://seer.ucp.br/seer/index.php?journal=synesis
} 
e) E finalmente, dedicavam-se à Ciência Divina, que considera as causas primeiras dos entes.

Justamente sobre os primeiros princípios existem alguns escritos que se dividem em diversas proposições, como que para que algumas verdades sejam consideradas separadamente. E, em grego, encontra-se algo desse tipo do platônico Proclo, contendo duzentas e onze proposições, que se intitula "Elementos de Teologia". E, em árabe, existe este livro, que entre os latinos é conhecido por "Sobre as Causas", que consta ser traduzido do árabe e não existir em grego. Donde parece ter sido extraído por algum dos filósofos árabes do mencionado livro de Proclo, especialmente porque tudo que se encontra neste livro está de modo mais completo e amplo naquele.

\section{Proposição I, lição I}

Expõe-se a primeira proposição como princípio de toda a obra

Toda causa primeira tem mais influência sobre seu efeito do que a causa universal segunda. Pois tirada a virtude da causa universal segunda sobre a coisa, a causa primeira não cessa sua virtude sobre ela. Isso acontece porque a causa universal primeira age sobre o efeito da causa Segunda, antes que a causa universal segunda aja sobre o mesmo, da qual segue o próprio efeito. Portanto, quando age a causa Segunda, da qual segue o efeito, não se exclui do mesmo efeito a ação da causa primeira, que está sobre ela. E, quando se separa a causa segunda do efeito que por ela se atingiu, não se separa do mesmo efeito a causa primeira que está sobre a coisa, pois é sua causa. E tomemos como exemplo disso o ser, o vivente e o homem. Ou seja, é necessário que na coisa venha primeiro o ser; em seguida, o vivente; e depois, o homem. O vivente é causa próxima do homem e o ser, causa remota. O ser é, pois, causa mais forte do homem do que o vivente, pois o ser é causa no vivente, que é causa no homem. Igualmente, quando dizemos que o racional é causa do homem, o ser do homem é mais veementemente causa do mesmo do que o racional, porque é causa de sua causa.

O sentido de tudo isso é que, quando se remove a virtude racional do homem, não permanece o homem, mas permanece o vivente sensível que respira. Enquanto que, quando se separa do mesmo o ser vivo, ou o que é vivo, ainda assim permanece o ser, porque o ser não se 
separa do mesmo, senão que aquilo que se separa é o vivo, porquanto a causa não é removida ao se remover seu efeito, por conseguinte permanece o ser. Destarte, quando o indivíduo já não é homem, é ainda animal; quando já não é animal, é somente ser. Fica, então, manifesto e evidente que a causa remota é a primeira, e qual a causa primeira é a causa da coisa de modo mais veemente e presente do que a causa próxima. Em razão disso, sua operação adere de um modo mais veemente que a operação da causa segunda ou próxima. Isso acontece porque a coisa recebe principalmente e em primeiro lugar a ação da virtude remota; e só depois recebe a ação da segunda, que está sob a primeira.

A causa primeira ajuda a segunda em sua operação, porque toda operação que a causa segunda realiza, a causa primeira também realiza, de modo que a causa primeira age de modo mais elevado e sublime. E quando se remove a causa segunda de seu efeito, não se remove dele a causa primeira, porque a causa primeira tem maior e mais veemente adesão à coisa do que a causa próxima. Isso porque a causa segunda só age por força da causa primeira. Em outras palavras, porque quando a causa segunda produz a coisa, a causa primeira, que está sobre a segunda, influi com sua força sobre aquela coisa, na medida em que adere àquela coisa com adesão mais veemente e, assim, a conserva. Fica manifesto e evidente que a causa remota é uma causa mais intensa da coisa do que a causa próxima a ela adjacente; como também se deve dizer que a mesma influi sobre a sua virtude e a conserva e não se separa dela pela separação da causa próxima, já que adere à coisa com forte adesão, consoante o que defendemos e expusemos.

\section{Comentário}

A intenção deste livro, chamado de "Sobre as causas", é de determinar as causas primeiras das coisas. E como por causa se entende certa ordem, e nas causas há certa ordem, o autor apresenta a proposição como princípio que domina toda a obra. Esta proposição refere-se à ordem das causas e formula-se assim: Toda causa primeira tem mais influência em seu efeito do que a causa segunda universal.

E, para comprovar isso, o autor aduz um corolário mediante o qual, como que por um sinal, se explicita a proposição. Por isso acrescenta que quando se remove a influência da causa segunda universal sobre a coisa, não se remove a influência da causa primeira universal sobre ela. 
E para provar isso aduz um terceiro, dizendo que isso acontece porque a causa universal primeira age sobre o efeito da causa Segunda, antes que a causa universal segunda aja em vista do mesmo efeito. Daí se conclui convenientemente como o que se havia exposto em segundo lugar, pois é necessário que o que é anterior na chegada seja o último a ser removido. Com efeito, as coisas que são anteriores na composição são as últimas na resolução.

Destarte, a intenção desta proposição divide-se em três partes, a primeira delas afirma que a causa primeira influi mais no efeito do que a causa segunda; depois, que a impressão da causa primeira demora mais em separar-se do efeito; e a terceira, que a causa primeira advém ao efeito por primeiro. Proclo examina essas três partes em duas proposições. A primeira, na proposição LVI de seu livro, diz: Tudo aquilo que é produzido pelas causas segundas, é produzido de modo mais eminente por causas anteriores e mais universais pelas quais as próprias causas segundas foram produzidas. A proposição seguinte, LVII, que inclui os outros pontos, afirma: Toda causa opera antes do efeito e produz depois dele muitos efeitos. Postas estas premissas, o autor, para esclarecê-las, procede primeiramente por um exemplo; depois, por um raciocínio, que diz que toda causa primeira ajuda à segunda.

O exemplo parece pertencer às causas formais, as quais, quanto mais universais, maior anterioridade parecem ter. Se tomarmos o homem, verifica-se que a sua forma específica está na racionalidade; a forma genérica, porém, em que é vivo ou animal. Posteriormente, aquilo que é comum a todos, o ser.

É manifesto que na produção de um homem particular, o ser é encontrado primeiramente em seu sujeito material, em seguida o vivente e, por último, o homem. Com efeito, primeiro é o animal e depois o homem, como se dia no II De generatione animalium. Ademais, sobre o caminho que conduz à corrupção, o homem perde primeiramente o uso da razão, mas permanece vivo e respirando; segundo, tiradas a vida e a respiração, permanece o próprio ente, porque não se corrompe no nada. Pode-se então compreender este exemplo consoante a ordem da geração e da corrupção do indivíduo, o que é patente no autor quando diz: Quando o indivíduo não é um homem — isto é, segundo o ato próprio do homem —, é animal, porque permanece nele a operação animal que consiste no movimento e na sensação; e quando não é animal é ser simplesmente, pois permanece o corpo totalmente inanimado. Este exemplo verifica-se também na ordem mesma das coisas: de fato, os existentes são anteriores aos viventes; os viventes, ao 
homem, já que, sendo removida o homem, não é removido o conteúdo de animal. E ao contrário: se não há animal, não há homem. O mesmo raciocínio vale para o animal e o ser.

Em seguida, quando diz: E a causa primeira..., o autor prova pela razão os três pontos expostos anteriormente. Por primeiro, demonstra que a causa primeira é mais influente que a segunda, pois tudo aquilo que convém ao efeito, convém eminentemente à causa. Ora, a operação pela qual a causa segunda causa o efeito é causada pela causa primeira. De fato, a causa primeira ajuda a causa segunda, pois a faz operar. Portanto, a operação da causa segunda pela qual esta produz seu efeito é mais um feito da causa primeira do que da segunda. Proclo prova-o de modo mais explícito: a causa segunda, porque é efeito da primeira, tem sua substância da primeira. Ora, é por aquilo que algo tem substância é que tem potência de operar. Portanto, a causa segunda tem potência ou virtude de operar pela causa primeira. Daí é pela potência ou virtude desta que a causa segunda causa o efeito. Portanto, o fato mesmo de que a causa segunda seja a causa do efeito provém da causa primeira. Também o poder de ser causa do efeito é inerente primeiro à causa primeira, em seguida, à causa segunda. Aquilo que é anterior em todas as coisas é mais, porque o que é mais perfeito é por natureza, anterior. Portanto, a causa primeira é mais causa do efeito do que a causa segunda.

Segundo, que a impressão da causa primeira tarda mais em receder do efeito, e prova isso quando diz: E quando é removida... Aponta, então, esta razão: aquilo que com mais força afeta algo é mais inerente. Ora, a causa primeira impressiona mais veementemente o efeito do que a causa segunda, como se provou. Logo, sua impressão é mais inerente; logo, mais tardiamente recede.

Terceiro, que a causa primeira chega antes no efeito. Prova pelas palavras: E não faz..., e com o seguinte argumento: a causa segunda não age sobre seu efeito se não for pela virtude da causa primeira. Logo, o causado não procede da causa segundo senão pela virtude da causa primeira. Assim, a causa primeira permite ao efeito ser atingido pela virtude da causa segunda. 亡̀, pois, tocado primeiramente pela virtude da causa primeira. Isto o prova Proclo por meio de um só termo. A causa primeira é mais causa do que a segunda. Portanto, é a mais perfeita das potências. Ora, quanto mais uma virtude é perfeita, tanto mais ela se estende a muitos; portanto, a virtude da causa primeira estende-se a mais efeitos do que a virtude da causa segunda. Ora, aquilo que está em várias coisas é primeiro no advir e último no receder. Portanto, a virtude da causa primeira advém por primeiro e recede por último. 
Consideremos agora em que tipos de causa esta proposição se aplica. Se a proposição se referir a diferentes gêneros de causa ${ }^{3}$, é manifesto que, segundo o modo de cada qual, é verdadeira para todos. O exemplo tomado pelo autor é tirado das causas formais. Mas uma razão similar é aduzida para as causas materiais. Com efeito, aquilo que é anterior na ordem da matéria é causa da matéria próxima como suporte, como a matéria primeira é substrato dos elementos que são por sua vez a matéria primeira dos corpos mistos.

O que acontece com ambas é o mesmo acontece com as causas eficientes. É manifesto que quanto mais uma causa eficiente é anterior, mais sua virtude se estende a um grande número de efeitos. Donde é necessário que o efeito mais próprio da causa eficiente primeira seja o mais comum. O efeito próprio das causas segundas se observa em um número menor de coisas; também é mais particular. A causa primeira produz e move a causa segundo o agente e, assim, é a causa de sua ação.

Com efeito, é sobretudo para as causas eficientes que valem os três pontos estabelecidos por esta primeira proposição. Donde é manifesto que é derivadamente que eles se aplicam às causas formais. O autor emprega o verbo influir quando Proclo usa o termo produção, que exprime a causalidade da causa eficiente. Todavia, não é evidente que se possa aplicar às causas materiais o que serve para as causas eficientes, porque as causas eficientes finitas não produzem a matéria, mas sim, a forma. Se considerarmos, entretanto as causas universais donde procedem os princípios materiais das coisas, deve-se admitir que a ordem das causas se propaga das causas eficientes às causas materiais. De fato, porque a eficácia ou a causalidade da causa primeira e suprema se estende a várias coisas, é necessário que aquilo que primeiramente subsiste em todas as coisas seja o efeito da causa primeira de tudo. Em seguida, acrescentam-se certas disposições às causas segundas, disposições pelas quais as matérias são apropriadas pelas coisas singulares. Isto se manifesta também entre as coisas que estão junto a nós. De fato, a natureza fornece a matéria primeira das coisas artificiais, pois, para certas artes particulares, a matéria natural apresenta-se como mais congruente para determinados artífices. Pode-se comparar a causa primeira de todas as coisas em relação à natureza inteira à relação que existe entre a natureza e a arte. Donde aquilo que por primeiro subsiste em toda natureza é efeito da causa primeira de todas as coisas, que se ajusta às coisas singulares por obra das causas segundas. Enfim, a proposição aplica-se manifestamente às causas finais. De fato, é por causa do fim último, que é universal, que todos os

\footnotetext{
3 Tomás refere-se aqui aos quatro gêneros aristotélicos de causa: a material, a formal, a eficiente e a final. NT. bttp:// seer.ucp.br/seer/index.php?journal=synesis
} 
outros fins são desejados, fins que o apetite busca e apetite que cessa diante do fim último. Mas a ordem observada nas causas finais se pode reduzir ao gênero das causas eficientes. De fato, o fim somente é causa enquanto move a eficiente a agir, de modo que ela pertence ao gênero da causa eficiente.

Contudo, se se investiga, em todos os gêneros das causas, se as considerações precedentes estão de algum modo ordenadas em todas as causas, é manifesto que não. Observa-se uma dupla ordem de causas: um modo por si; outro por acidente. A ordem por si dá-se quando a intenção da causa primeira leva até o último efeito por mediação das causas segundas. Assim, a arte do ferreiro move a mão, sua mão move o martelo, o qual pela martelada expande o ferro, que manifesta finalmente a intenção do artista. A ordem é por acidente quando a intenção da causa não vai além do efeito próximo. Quanto àquilo que o efeito provocará a mais, está além da intenção do agente primeiro. De modo que está além da intenção daquele que acende uma vela que ela por sua vez acenda outra, esta outra ainda e assim por diante. E aquilo que está além da intenção nós dizemos ser por acidente. A primeira proposição é verdadeira, portanto, nas causa ordenadas por si, nas quais a causa primeira move todas as causas intermediárias até o efeito. Porém, nas causas ordenadas por acidente, acontece o contrário, pois o efeito produzido por si pela causa próxima é produzido por acidente pela causa primeira, escapando de sua intenção. Como aquilo que é por si pode mais que aquilo que é por acidente, o autor fala de causa universal que é causa por si.

\section{Proposição II, lição II}

Os entes superiores pertencem a três graus, a saber: antes da eternidade, com a eternidade, depois da eternidade

Todo ser superior ou é superior e anterior na eternidade, ou é com a eternidade, ou depois da eternidade e acima do tempo. Ser antes da eternidade é ser causa primeira, que é a própria causa da eternidade. E o ser com a eternidade é a inteligência porque é o ente segundo um único modo de ser, por conseguinte não padece nem se destrói; enquanto que o ser que é depois da eternidade e que está acima do tempo é a alma, e porque é inferior está no horizonte da eternidade do mesmo modo que está acima do tempo.

E isso significa que a causa primeira é anterior à eternidade porque o ser que está na eternidade é adquirido. Digo, pois, que toda eternidade é ser, mas não que todo ser seja 
eternidade. Por conseguinte, o ser é mais comum que a eternidade. E a causa primeira está acima da eternidade, porque a eternidade por ela.

A inteligência é oposta ou equiparada à eternidade porque se estende com ela, e não se altera ou destrói.

A alma é aproximada à eternidade de modo inferior, porque é mais suscetível de impressão que a inteligência, mas está acima do tempo por ser a causa do tempo.

\section{Comentário}

Estabelecida a primeira proposição, que é o princípio de todo o tratado, o autor começa a expor sobre as causas primeiras das coisas. E divide sua exposição em três partes: a primeira, que trata da distinção das causas primeiras; a segunda, sobre a coordenação ou dependência das causas entre si, que começa com a proposição XVI: Todas as potências que não têm limites... A primeira parte está subdividida em duas: primeiramente, o autor trata da distinção das causas primeiras; depois, a partir da VI proposição, onde se diz que a causa primeira é superior..., trata de cada causa singularmente.

As causas universais são de três gêneros: a causa primeira, que é Deus; a inteligência e a alma. Em relação à primeira, estabelece três pontos: distingue esses três gêneros de causa, sendo que a causa primeira não é dividida, porque é única. Em seguida, distingue as inteligências, na proposição IV, onde diz que a primeira das coisas criadas é o ser... Enfim, na V proposição As inteligências superiores..., distingue as almas. Acerca do primeiro, o autor expõe dois pontos: distingue os três gêneros citados. $\mathrm{Na}$ proposição III, onde ele diz que toda alma nobre..., ele mostra como esses três gêneros estão unidos com o primeiro por certa participação.

Primeiramente, o autor apresenta a proposição: Todo ser superior ou está acima da eternidade ou diante dela ou com a eternidade, ou depois da eternidade e acima do tempo. Para entender tal proposição é preciso primeiro saber que é eternidade, depois em que sentido essa proposição é verdadeira.

O nome eternidade compreende certa indefectibilidade e infinitude, pois se diz eterno aquilo que existe fora dos limites. Porém, como diz o Filósofo no livro VIII da Física que toda mudança supõe certa corrupção e geração, na medida em que certa coisa começa a ser e outra cessa de ser, é necessário que em toda mudança exista certa deficiência, de modo que qualquer 
mudança repugne à eternidade. Já que a eternidade verdadeira importa a indeficiência do ser, ela também exige a imutabilidade. E como a anterioridade e a posterioridade no tempo provêm da que é observada na mudança, como aparece no livro IV da Física, é necessário, em terceiro lugar, que a eternidade pertença àquilo que existe todo inteiro simultaneamente, sem anterioridade ou posterioridade. Por isso Boécio define assim a eternidade em sua Consolação da Filosofia: eternidade é a posse perfeita, total, simultânea de uma vida interminável.

Toda coisa com indeficiência no ser tem imutabilidade, é sem sucessão temporal e pode ser dita eterna. E é por isso que platônicos e peripatéticos consideravam eternas as substâncias imateriais separadas, aditando à noção de eternidade a posse perene do ser, o que não é cônsono com a fé cristã. De fato, a eternidade só convém a Deus. Dizemos, porém, que certas substâncias são eternas enquanto que, começando a ser, elas recebem de Deus o ser perpétuo, indeficiente, sem mudança e sem sucessão temporal. Por isso Dionísio afirma, no capítulo X do De Divinis Nominibus, que "não são absolutamente coeternas a Deus as substâncias" que as Escrituras "chamam de eternas". Daí alguns chamarem de evo esta acepção de eternidade, para distinguirem da eternidade tomada no primeiro modo. Porém, estritamente considerando, evo e eternidade não diferem senão como diferem anthropos e homem: de fato, em grego, eternidade diz-se aevum como anthropos, homem.

É necessário saber que esta proposição pertence a LXXXVIII do livro de Proclo convenientemente expressa nos seguintes termos: "Todo ente autêntico ou está antes da eternidade, ou está na eternidade, ou participa da eternidade". Proclo opõe "ente autêntico" ao ente móvel, como permanecer em oposição a ser movido. Donde se pode compreender o que aí se diz: "todo ser superior", porque está acima do movimento e do tempo. Segundo ambos os autores e em ambas as obras, tal ser superior distingue-se em três graus; entretanto, a razão dessa divisão não é a mesma em um e em outro. Proclo chega a ela a partir de pressupostos platônicos, os quais, admitindo a abstração dos universais, defendiam que quanto mais alguma coisa é abstrata e universal tanto mais seu ser é anterior.

É evidente que o termo eternidade é mais abstrato que eterno. De fato, pelo nome eternidade designa-se a própria essência da eternidade, enquanto que o nome eterno designa aquilo que participa da eternidade. Ademais, o ser é mais comum que a eternidade. Com efeito, todo eterno é ente, mas nem todo ente é eterno. Donde, do que ficou dito, o próprio Ser separado é anterior à eternidade; o que está com a eternidade é o próprio ser sempiterno. Aquilo, 
porém, que participa da eternidade, como que depois da eternidade, é tudo aquilo que participa do ser eterno.

Quanto ao primeiro ponto, autor deste livro concorda com o que ficou dito, pois expõe que o ser que está antes da eternidade é Causa primeira, porque é causa da eternidade. Para provar isso, ele acrescenta que nela, isto é, na eternidade, o ser é adquirido, ou seja, é participado. E isso se prova porque o que é menos comum participa do que é mais comum. Ora, a eternidade é menos comum do que o ser; daí, continua: e digo que toda eternidade é ser, mas nem todo ser é eternidade. Logo, o ser é mais comum que a eternidade. Assim, pois, prova o autor que a eternidade participa do ser; o próprio ser abstrato ${ }^{4}$ é a causa primeira da qual a substância tem seu ser. Por conseguinte, a causa primeira é a causa pela qual toda coisa sempre existente adquire seu ser eterno.

Mas, nos outros dois pontos da divisão, o nosso autor afasta-se da intenção de Proclo e aproxima-se mais das sentenças comuns dos platônicos e peripatéticos. Desse modo, expõe o segundo grau, no qual o ser com a eternidade é a Inteligência; porque a eternidade, como se disse, compreende indeficiência e imobilidade, pois tudo aquilo que é indeficiente e imóvel toca a eternidade. É, pois, defendido pelos filósofos citados que a Inteligência ou o Intelecto separado tem indeficiência e imobilidade quanto ao ser, quanto à virtude e quanto à operação. Daí que, na proposição CLXIX, Proclo declare: Todo intelecto tem na eternidade substância, potência e operação. Por conseguinte, prova-se aqui que a inteligência está com a eternidade, porque ela é totalmente uma, de modo que não sofre nenhuma alteração, nem em sua potência, nem em sua operação, nem é destruída em sua substância. E, por causa disso, também diz posteriormente que ela é igualada à eternidade porque a esta se estende e não se altera. Com efeito, a eternidade estende-se a tudo que é próprio da Inteligência.

O terceiro grau é o da alma que tem um ser superior, ou seja, que está acima do movimento e do tempo. De tal modo que a alma se aproxima mais do movimento que a Inteligência, porque evidentemente a inteligência não é tocada pelo movimento nem segundo a substância, nem segundo a operação. A alma, porém, ultrapassa o tempo e o movimento e toca a eternidade, mas, segundo a operação, é atingida pelo movimento, já que, como estabelecem tais filósofos, é necessário que tudo que é movido o seja por e que seja levado a um primeiro que move a si mesmo. Este primeiro é, para Platão, a alma que se move por si mesma; para 
Aristóteles, porém, é o corpo animado cujo princípio de movimento é a alma. Assim, segundo um e outro, é necessário que o primeiro princípio do movimento seja a alma e que o movimento é a própria operação da alma. E porque o movimento tem lugar no tempo ele atinge a operação da própria alma.

Donde Proclo afirma na proposição CXCI “Toda alma participável tem uma substância eterna e uma atividade temporal". Afirma ainda que "a alma está ligada à eternidade de modo inferior". Ela está verdadeiramente ligada à eternidade Quanto à sua substância de modo inferior porque ela participa em menor grau da eternidade do que a inteligência. $O$ autor prova isso quando diz que "ela é mais suscetível de impressão do que a inteligência". A alma de fato não só recebe impressão da causa primeira, como a inteligência, mas também recebe impressão da inteligência. Ora, quanto mais uma coisa é distante do primeiro, que é a causa da eternidade, tanto mais debilmente participa da eternidade. E, embora a alma atinja a eternidade em grau ínfimo, ela permanece acima do tempo, como a causa acima do causado: de fato é a causa do tempo enquanto é causa do movimento para o qual o tempo segue. Ora, fala-se aqui a respeito da alma aquilo que os filósofos atribuem aos corpos celestes e, por causa disso, ela está num "grau inferior no horizonte da eternidade e acima do tempo". O horizonte é, com efeito, o círculo limitador da visão e é o limite ínfimo do hemisfério superior assim como princípio do inferior. Igualmente é a alma o último limite e princípio do tempo.

Dionísio concorda com tal sentença no capítulo X do De Divinis Nominibus excetuando que não afirma que o céu tenha alma, pois isto a fé católica não afirma. Diz, com efeito, que "Deus está acima da eternidade" e isso se compreende de acordo com as Escrituras, que dizem que algumas coisas são eternas e temporais; isso deve ser entendido segundo o modo estabelecido nas Sagradas Escrituras: “em meio às coisas existentes e produzidas - isto é as coisas geradas existem realidades que segundo certo aspecto são eternas, e segundo outro participam do tempo”.

\section{Proposição III, lição III}

De que modo a alma participa do Primeiro e do segundo

Toda alma nobre tem três operações: de fato, entre suas operações estão a animal, a intelectual e a divina. Esta operação é divina porque ela mesma prepara a natureza conforme a virtude que nela existe graças à Causa Primeira. Sua operação é intelectual porque ela sabe as 
coisas em virtude da inteligência que está nela mesma. É animal porque move o primeiro corpo e todos os corpos naturais, e porque ela é causa do movimento dos corpos e causa da operação da Natureza. E a alma só realiza tais operações porque ela é o exemplo da virtude superior, o que quer dizer que a alma só realiza tal operação divina porque a Causa primeira causou o seu ser mediante a Inteligência. Portanto, depois que a Causa primeira criou o ser da Alma, pô-la como receptáculo da Inteligência na qual realiza suas operações. Por causa disso, a Alma intelectual realiza operação intelectual; e porque a Alma recebe a impressão da Inteligência, foi dotada de operação inferior à da mesma na impressão sobre aquilo que lhe está submetido. Isso acontece porque a própria alma causa impressão em uma coisa a não ser pelo movimento, ou seja, porque uma coisa que lhe está submetida não recebe a operação da alma senão quando esta a move. É, pois, por causa disso que a alma move os corpos; é, pois, propriedade da Alma vivificar os corpos quando sua virtude exerce seu influxo sobre eles e diretamente os conduz à reta operação. É, pois, manifesto que a alma tem três operações, porque tem três virtudes, a saber: a virtude divina, a virtude intelectual e a virtude da sua essência, segundo o que expusemos e defendemos.

\section{Comentário}

Porque aquilo que pertence às coisas superiores se encontram nas inferiores segundo certa participação, o autor, depois de dividir três graus de entes superiores, a saber: o que está acima da eternidade, isto é, Deus; outro que está na eternidade, a Inteligência; e um terceiro, que está depois da eternidade, a Alma, procura mostrar como o terceiro participa do primeiro e do segundo graus, dizendo: Toda alma nobre tem três operações: de fato, entre suas operações estão a animal, a intelectual e a divina. Pode-se compreender o que se entende por Alma nobre a partir das palavras de Proclo na proposição CCI: Todas as almas divinas têm tríplice operação: operam como almas; outras como o que recebeu o intelecto divino; outras ainda como que extrinsecamente unidas aos deuses. A partir disso fica evidente que Alma nobre é o que Proclo chama de alma divina.

Isso fica evidente ao se ter presente que Platão defendeu que as formas universais das

coisas eram separadas e per se subsistentes. E, igualmente, porque essas formas universais exercem certa causalidade universal sobre os entes particulares que delas participam, chamava 
todas essas formas subsistentes de deuses, já que o nome deus implica certa providência e causalidade universais. Platão dispunha essas formas na seguinte ordem: quanto mais universal é uma forma, mais ela é simples e causa anterior; com efeito, ela é participada pelas formas posteriores. Destarte, o animal é participado pelo homem; a vida pelo animal e assim por diante. O último, porém, do qual todos participam, e que não participa de nenhum outro, é o próprio Uno e Bem Separado que era chamado de Sumo Deus e Causa Primeira de todas as coisas. O que pode ser inferido da proposição CXVI do livro de Proclo: Todo deus é participável, isto é, participa, exceto o Uno. E porque essas formas, que chamavam de deuses, são inteligíveis em si mesmas, e que, entretanto, o intelecto só se torna em ato inteligente pela espécie inteligível, eles situaram sob a ordem dos deuses, ou das formas citadas, a ordem dos intelectos que participam dessas formas para se tornarem inteligentes. E, entre essas formas, está também o Intelecto Ideal. Mas esses intelectos participam das mencionadas formas segundo um modo imóvel, enquanto eles as entendem. Donde, sob a ordem dos intelectos, punham uma terceira ordem, a das almas que, mediante os intelectos, participam das sobreditas formas segundo o movimento, e, assim, são princípios dos movimentos corpóreos, pelas quais as formas superiores são participadas pela matéria. Eis que a quarta ordem das coisas é a ordem dos corpos.

Contudo, entre os intelectos superiores, diziam que alguns eram divinos, e que outros, inferiores, embora certamente intelectos, não eram divinos, porque o Intelecto ideal, que, segundo os mesmos, é por si deus, é participado pelos intelectos superiores de dois modos, a saber: enquanto é intelecto e enquanto é deus; pelos inferiores, somente enquanto é intelecto e não como intelectos divinos. Com efeito, cabe aos intelectos superiores não somente serem intelectos, mas também serem divinos.

Igualmente, as almas quando alcançam os deuses mediante os intelectos que lhes são mais próximos, essas almas superiores também são divinas por causa dos intelectos divinos aos quais se ligam ou participam; as almas inferiores, porém, não são divinas porque se unem a intelectos nãodivinos.

E os corpos, porque não recebem o movimento senão pelas almas, segue-se que, segundo os mesmos, os corpos superiores são divinos, enquanto que os inferiores não o são. Donde o dizer de Proclo na proposição CXXIX: Todo corpo é divino pela alma deificada; toda alma é divina por causa do intelecto divino; e todo intelecto é divino consoante sua participação na unidade divina. 
E porque chamavam deuses às primeiras formas separadas por serem por si universais, diziam que os intelectos, as almas e os corpos eram divinos na medida em que tinham influência e causalidade universais sobre o que lhes segue no mesmo gênero e em gêneros inferiores.

Dionísio corrige essa posição que consiste em distribuir ordenadamente as diversas formas separadas, chamadas de deuses, de modo que uma coisa seria a bondade em si, outra seria o ser em si, outra ainda, a vida em si, e assim por diante.

É, pois, necessário dizer que todas essas coisas são essencialmente a mesma Causa primeira de tudo, pela qual as coisas desse modo participam de todas as perfeições e, assim, não defendemos vários deuses, mas somente um. E é o que diz o capítulo V do De divinis nominibus: a Sagrada Escritura diz que "não é uma coisa o bem, outra o existir, outra a vida ou a sabedoria, nem que há muitas causas e divindades produtoras de outras, excedentes e subordinadas, mas que todos os bens procedem de Um só princípio.

A partir daí, Dionísio mostra consequentemente como isso acontece: porque Deus é o próprio ser e a própria essência da bondade, tudo aquilo que pertence à perfeição da bondade e do ser Lhe convém total e essencialmente, quer dizer, o Próprio é a essência da vida, da sabedoria, da virtude e de tudo mais. Por isso, em seguida acrescenta: “com efeito, Deus não existe de um modo qualquer, mas ele compreende tudo em seu ser de modo absoluto e sem limites".

O autor deste livro segue o que diz Dionísio: verdadeiramente não há nada nele que induza a uma multiplicidade de divindades, mas o autor defende a Unidade em Deus e, não obstante, a distinção na ordem das inteligências, das almas e dos corpos.

Dessa forma, chama-se, pois, alma nobre ou divina a alma do corpo celeste, conforme a opinião dos filósofos que defenderam um céu animado. Essa alma, segundo eles, tem, devido ao movimento, certa influência universal sobre as coisas e por isso se chama divina; de igual modo se diz que, entre os homens, os que têm o cuidado universal da coisa pública são divinos.

Defende ainda que essa alma nobre ou divina tem operação divina. Ao expor isso, afirma que sua operação divina existe porque ela prepara a Natureza na medida em que é princípio do primeiro movimento ao qual toda a natureza está submetida. E é tal pela potência participada da causa primeira que é a causa universal de todas as causas e da qual a alma recebe certa causalidade universal sobre as coisas naturais. E, por isso, depois de indicar que essa operação é própria da Alma divina, diz adequadamente que a mesma é exemplo, isto é, imagem de uma potência superior, a saber, divina. Em tal alma se exemplifica a universalidade da potência divina, porque, 
do mesmo modo como Deus é a causa universal de todos os entes, assim essa Alma é a causa universal das coisas naturais que se movem.

A segunda operação da Alma nobre ou divina é considerada intelectual, porque, como expõe o autor, ela conhece todas as coisas na medida em que participa da potência da inteligência. Mostra também por que ela participa da potência da inteligência: porque a alma foi criada pela causa primeira mediante a inteligência. Portanto, a alma depende de Deus como sua causa primeira, da inteligência como sua causa segunda. Por outro lado, todo efeito participa em alguma medida da potência de sua causa, donde resulta que a alma assim como tem operações divinas porque depende da causa primeira, ela realiza a atividade intelectual porque, ao depender da inteligência, é partícipe de sua potência.

A partir do que foi dito, que a causa primeira criou o ser da alma mediante a inteligência, alguns julgaram mal pensando que o autor desse livro quisesse sustentar que as Inteligências fossem criadoras da substância das almas.

Isso, contudo, é contrário às posições platônicas: de fato, defendiam que tais causalidades dos entes simples se exerciam segundo a participação. É, pois, participado não certamente aquilo que é participante, mas o que é primeiro, ou seja, o que é tal por essência. Por exemplo, se a brancura existisse separada, a própria brancura simples seria a causa de todas as coisas brancas, enquanto brancas, e não algo que participasse da brancura. Consoante isso, os platônicos consideravam o próprio ser como causa da existência de todas as coisas. Igualmente, a vida mesma seria a causa de todos os que vivem; e a inteligência mesma, a causa de tudo aquilo que entende. Donde o dizer de Proclo na proposição XVIII de seu livro: Todo aquele que dá o ser a outros é por primeiro aquele cuja doação é transmitida aos receptores. Tal sentença é concorde com o que diz Aristóteles no II livro da Metafísica: aquilo que é primeiro e ente em grau máximo é causa de tudo que lhe segue.

Portanto, deve-se entender, segundo o exposto, que a própria essência da alma é causada pela causa primeira que é o seu próprio ser; contudo, tem suas participações seguintes em princípios posteriores: assim, o viver participa da vida primeira; o entender, da inteligência. Daí que também a proposição XVIII desse livro afirme: Todas as coisas têm essência pelo ente primeiro; todas as coisas vivas são movidas, em razão de sua própria essência, pela vida primeira, e todas as coisas intelectivas têm conhecimento por causa da inteligência primeira. Assim, pois, entende que a causa primeira causou o ser da alma mediante a inteligência, ou seja, que somente a 
causa primeira causou a essência da alma, mas que a alma seja intelectiva, isso se dá pela operação da inteligência.

Esse sentido é claramente manifesto pelas palavras que se seguem: portanto, depois que a causa primeira causou o ser da alma, fixou-a como suporte da inteligência, isto é, tornou-a subjacente à operação da inteligência para que a inteligência exerça nela sua operação, ou seja, torne-a intelectual. Donde conclui que, por causa disso, a alma intelectual exerce operação intelectual. E isso concorda também com o que se diz na proposição I, que o efeito da causa primeira preexiste ao efeito da causa segunda e se difunde de modo mais universal. Com efeito, o ser, que é comuníssimo, se difunde em todas as coisas pela causa primeira, mas o entender não é comunicado a todos pela inteligência, mas a alguns, pressupondo o ser que têm do Primeiro.

Mas também esta posição, se não é corretamente entendida, repugna à verdade e ao pensamento de Aristóteles, o qual argumenta no livro III da Metafísica contra os platônicos, que defendem semelhante ordem de causas separadas consoante as coisas que se predicam do indivíduo. Donde se segue que Sócrates será muitos animais, isto é, o próprio Sócrates será homem separado e animal separado: com efeito, homem separado participa de animal e, assim, é animal; Sócrates, porém, participa de ambos, donde é homem e é animal. Sócrates, de fato, não seria verdadeiramente um se, por um princípio, devesse ser animal e, por outro, homem.

Portanto, como o ser intelectual pertence à própria natureza da alma, na medida em que é a sua diferença essencial, se tivesse o ser de um princípio e a natureza intelectiva de outro, se seguiria que não seria absolutamente una. É necessário, portanto, dizer que é pela causa primeira que ela tem essência e também intelectualidade. $\mathrm{E}$ isto está de acordo com o pensamento supracitado de Dionísio, que defende que o próprio bem, o próprio ser, a própria vida e a própria sabedoria não são distintos, mas um e mesmo ser, que é Deus, do qual todas as coisas recebem o ser, o viver e o conhecer. Também Aristóteles, no livro XII da Metafísica, atribui explicitamente a Deus o entender e o viver, dizendo que Ele mesmo é a vida e a inteligência, para excluir as posições platônicas antes mencionadas.

Entretanto, essa doutrina pode de algum modo ser verdadeira se se refere não à natureza intelectual, mas às formas inteligíveis que as almas intelectivas recebem pela operação das inteligências; daí que Dionísio diga no capítulo IV do De Divinis Nominibus que as almas pelos anjos se fazem partícipes das iluminações que emanam de Deus. 
Com efeito, o autor estabelece que a terceira operação da alma nobre ou divina é animal. E expõe ainda que a operação animal consiste nisto: que ela mesma move o primeiro corpo e, em consequência, todos os corpos naturais, ou seja, que ela é verdadeiramente a causa do movimento nas coisas.

E o autor indica ulteriormente a razão disso: porque a alma é inferior à inteligência, dado que recebe uma impressão da inteligência, segue-se daí que a alma age em todas as coisas que lhe estão submetidas como a Inteligência exerce sua impressão sobre as coisas que lhe estão sujeitas. Ademais, ficou manifesto na proposição I que a causa primeira influi mais do que a segunda. Contudo, a inteligência causa sua impressão na alma sem que haja movimento, quando, por exemplo, faz a alma conhecer, o que não implica movimento. Mas a alma age no corpo pelo movimento e o que lhe está sujeito, isto é, o corpo não recebe a impressão da alma a não ser enquanto é movido por ela.

Em seguida, o autor indica a causa pela qual se deve dizer que o movimento dos corpos procede da alma. Vemos, com efeito, que os corpos naturais chegam diretamente por suas operações e movimentos a seus próprios fins, o que não se poderia dar se não fossem dirigidos por alguma coisa inteligente. Donde se vê que o movimento dos corpos provém da alma que imprime sua potência sobre eles, movendo-os.

E tal proposição, que diz que o movimento do céu provém da alma, também nos é ratificada pela fé. E embora Santo Agostinho deixe isso em dúvida no II livro Super Genesim ad litteram, o mesmo no III livro Sobre a Trindade e Gregório no IV livro Dialogorum afirmam que Deus dirige toda a natureza e move a criatura corpórea pela mediação das Inteligências ou anjos.

Por fim, o autor conclui aquilo a que se propôs, ou seja, mostrar que a alma nobre tem as três operações supracitadas. O que foi dito sobre o intelecto divino e a alma divina concorda com o pensamento de Dionísio que, no capítulo IV do De divinis nominibus, chamas os anjos superiores de mentes divinas, isto é, intelectos pelos quais as almas participam, segundo a sua potência, de um dom deiforme.

Mas essa divindade é recebida consoante a união com Deus, e não conforme o influxo universal exercido sobre as coisas causadas. Com efeito, isso também é mais divino, pois, em Deus mesmo, aquilo que Ele é mais do que o que ele causa em outros.

Proposição VI, lição VI 


\section{Sobre a Causa Primeira}

A causa primeira é superior a tudo que podemos narrar, e a língua é incapaz de narrá-la justamente porque não pode dizer o que é o seu próprio ser, pois a causa primeira está acima de toda causa; e só pode ser enunciada mediante as causas segundas, que são iluminadas pela luz da causa primeira. Isso significa que a causa primeira não cessa de iluminar seu efeito, enquanto que ela mesma não é iluminada por nenhuma outra luz; pois a própria causa primeira é luz pura a tal extremo que sequer é luz, porque nada há de superior a ela, mas ela mesma está acima de todas as coisas. Daí resulta que, sendo a única primeira, toda declaração sobre ela será deficiente; e isto se deve a que não existe nenhuma causa acima da mesma que nos possa fazer conhecê-la, pois toda coisa só é conhecida e narrada pela causa primeira.

Consequentemente, por ser somente causa e não causada, a causa primeira não é conhecida nem narrada, porque é superior a toda narração e está fora do alcance do discurso, que acontece ou se explica porque a narração só se efetua mediante a palavra ou linguagem; e a linguagem pela inteligência; e a inteligência pelo pensamento; e o pensamento pela meditação; e a meditação pelo sentido. Porém, a causa primeira está acima de todas estas coisas por ser causa das mesmas. Do que se depreende que não está nem ao alcance do sentido, nem da meditação, nem do pensamento, nem da inteligência, nem da palavra. Por conseguinte, é inefável e inenarrável. Repito, pois, que a coisa, sendo sensível, cai sob o domínio do sentido; ou é capaz de ser meditada, sendo então objeto de meditação; ou tem um modo de ser estável e fixo, segundo uma única disposição, e então é inteligível; ou então é mutável e destrutível, estando sujeita ao processo de geração e corrupção, em então cai sob a órbita ou raio da ação do conhecimento (pensamento). Porém como a causa primeira está acima de todas as coisas, tanto inteligíveis e sempiternas como das coisas destrutíveis, está, por isso mesmo, fora do alcance tanto da meditação, como do sentido e da inteligência. De modo que só pode ser concebida e expressa de algum modo pela causa segunda que é a inteligência, existindo ela mesma, conforme manifestamos, de um modo mais sublime, mais nobre e melhor.

\section{Comentário}


Até aqui, o autor do livro dividiu em três graus o ser superior considerado de um modo geral, declarando que no primeiro grau está o ser acima da eternidade e que este ser se identifica com a causa primeira; no segundo grau está compreendido o ser que é ou existe com eternidade, que se identifica com a inteligência; enquanto que no terceiro grau está o ser que, embora esteja abaixo da eternidade, está, entretanto, acima do tempo, e este ser corresponde à alma.

O autor começa agora a discorrer sobre cada um dos graus em particular, começando pela causa primeira. Em segundo lugar, trata da inteligência em outra proposição que se inicia com as seguintes palavras: "A inteligência e a substância”; tratando, em terceiro lugar, da alma, na décima quarta proposição, quando diz: "Em toda alma".

O principal que podemos saber sobre a primeira causa se reduz a dizer que supera toda ciência e toda expressão, pois o modo mais perfeito que temos de conhecer a Deus consiste em declarar que tudo quanto se pode pensar ou dizer do mesmo é inferior ao que Deus é. Por isso diz Dionísio no livro X de sua Teologia Mística que o homem expressa melhor seu conhecimento de Deus dizendo que é totalmente desconhecido, no sentido de que nada conhece do mesmo, porque sabe que está acima de toda mente. Para demonstrar isso, serve-se da seguinte proposição: A causa primeira é superior a toda narração. E entende por narração a afirmação, pois qualquer coisa que afirmemos dele, não lhe convém no sentido em que nós lhe possamos dar, já que os nomes que lhe atribuímos têm seu sentido segundo nossa maneira de entender; é assim que o ser divino transcende esta maneira de entender. Por tal motivo Dionísio afirma, no segundo capítulo da Hierarquia Celeste, que as negações aplicadas aos atributos divinos são verdadeiras, enquanto que as afirmações são incompletas ou inconvenientes. Esta mesma proposição é formulada por Proclo nos seguintes termos, na proposição CXXIII de seu livro: embora tudo aquilo que o próprio ente tem de inefável e incógnito para todos os entes segundos, por sua própria união supersubstancial, entretanto, pode ser captado e conhecido pelos entes que participam do mesmo, por cujo motivo o primeiro ente só é absolutamente ignoto por ser ente imparticipável ou não participável.

Quando diz que o ente entende toda forma ideal, adota as posições dos platônicos que sustentavam que a forma ideal de todas as coisas existia separada de seus indivíduos, de modo que segundo eles existia o homem por si mesmo como idéia, assim a vida por si mesma, e outras idéias semelhantes, conforme dissemos. Mas como segundo os mesmos platônicos estas formas ideais gozam de unidade supersubstancial que está destinada a ser participada por todos os 
sujeitos, por isso diz que cada um deles não pode ser anunciado nem conhecido pelos seres inferiores, enquanto que pode ser conhecido pelos superiores: por exemplo, a idéia de vida pode ser conhecida pela idéia de ente.

Porém, por mais que não possam ser narrados nem conhecidos perfeitamente pelos seres inferiores, entretanto podem ser descritos (mais que definidos) e conhecidos de algum modo através daqueles que participam dos mesmos; de modo que através daqueles que participam da vida, algo se pode saber da própria vida. Em contrapartida, segundo os platônicos, aquele que é simplesmente primeiro, ou seja, a essência mesma da bondade, é absolutamente desconhecido, o que significa a palavra imparticipável, isto é, que tem existência que não é posterior a nada, ou a nenhuma existência.

Porém, como o autor deste livro não está de acordo com os platônicos acerca da doutrina que admite a existência de outras naturezas separadas, senão que somente admite um único primeiro, conforme vimos; por isso, fazendo caso omisso das demais naturezas separadas trata desta causa primeira e diz da mesma que é superior a quanto se pode dizer. E assinala a causa desta inefabilidade, dizendo que inefável por sua própria supersubstancialidade, como Proclo; e isto é o que significa o que segue depois na mesma proposição: "E a fala não alcança anunciá-la a não ser quando trata de anunciá-la pelo não ser da mesma”; porque a mesma está sobre toda causa. E explica como é anunciada, dizendo depois: "Não é anunciada senão através das causas segundas, que são iluminadas pela luz da causa primeira". Isso concorda com o que disse Proclo ao indicar que é suscetível de ser entendida através dos que participam do mesmo (de modo imperfeito).

A afirmação contida na proposição se demonstra do seguinte modo, tendo em conta de antemão que algo pode ser conhecido de três modos. De um modo como o efeito é conhecido através da causa; de outro modo, quando algo é conhecido diretamente em si mesmo e por si mesmo; e de outro modo quando algo é conhecido através do efeito.

Deve-se descartar o primeiro modo de conhecer no caso da causa primeira, pois diz o autor que o conhecimento pela própria causa não tem lugar, pois, "a causa primeira não cessa de iluminar seus efeitos, enquanto que ela não é iluminada por outra luz, por ser ela mesma luz pura até o ponto que sobre ela mesma não existe outra luz". Para entender melhor esta maneira de se expressar deve-se ter em conta que as coisas visíveis que afetam sensivelmente o sentido da vista, 
são conhecidas mediante a luz; daí a comparação que entende por luz aquilo pelo que algo é conhecido.

Porém, o Filósofo prova, no livro IX da Metafísica, que qualquer coisa que é conhecida o é mediante o ato da própria coisa; em outras palavras, só nos é conhecida uma coisa mediante seu estado em ato, de modo que a atualidade da coisa é como que certa luz da mesma. E pelo mesmo motivo que o efeito deve à causa o estar em ato, daí resulta que o efeito é iluminado e conhecido por ou através de sua causa. Porém, como a causa primeira é ato puro até o ponto de não ter nenhuma possibilidade adjunta, pela mesma razão a causa primeira é luz pura da qual provém que as outras coisas sejam iluminadas e resultem inteligíveis. E daí deduz a conclusão ulterior, a saber, que só a causa primeira não pode narrar-se ou ser contada porque não tem uma causa superior pela qual possa ser narrada. Pois as coisas costumam ser narradas por suas causas. E como a narração supõe o conhecimento, demonstra o autor que é preciso que a causa primeira supere toda narração pelo fato mesmo de que não é alcançada por nenhum conhecimento (relativo ou extrínseco à mesma): pois a narração se expressa pela fala, ou pelo discurso falado; e a fala requer o entendimento da coisa, pois as vozes que têm algum significado são sinais das coisas entendidas. Porém, a inteligência de uma coisa supõe o conhecimento que resulta do raciocínio, que é indiscutível tratando-se dos homens que, mediante o raciocínio chegam ao conhecimento da verdade; do mesmo modo que a concepção da idéia supõe a meditação, ou seja, o pensamento supõe a imaginação e todas as demais forças sensitivas inferiores que servem à razão humana. Porém, a imaginação se obtém através dos sentidos, pois a fantasia é um movimento que provém do sentido enquanto está em ato, segundo consta pelo livro II Sobre a Alma. Consequentemente, a causa primeira supera todos os procedimentos enumerados por estar acima de todas as coisas.

Outro tanto afirma Dionísio, no cap. I Sobre os Nomes Divinos, quando escreve que a causa primeira está fora do alcance do sentido e da fantasia, que este autor chama de meditação; tampouco a alcança a opinião, que este chama de razão; como tampouco expressa o nome que este autor chama fala ou discurso falado; como tampouco a alcança o sermão que este autor chama de narração; e por último, tampouco a alcança a ciência que este autor chama de inteligência.

Em segundo lugar, passa o autor a demonstrar que tampouco é conhecida a primeira causa por si mesma, ou seja, conforme o segundo modo anunciado de conhecer. Isto é demonstrado recorrendo e descartando as diversas modalidades desta maneira de conhecer. 
Pois há coisas que diretamente são conhecidas pelos sentidos, como as coisas sensíveis: outras coisas são conhecidas pela meditação ou imaginação, como as coisas imagináveis que estão sujeitas ao sentido; outras coisas são conhecidas pelo entendimento, como as coisas necessárias e imóveis; enquanto que outras são conhecidas pela razão (reflexão) como as coisas geráveis e corruptíveis. Sobre este modo de conhecer diz o Filósofo o livro VI da Ética, que o raciocínio versa sobre aquelas coisas que se transformam ou mudam. Porém, porque a causa primeira está acima de todo esse gênero de coisas ela não pode ser conhecida por nenhuma das modalidades enumeradas. A mesma prova é aduzida por Proclo, com a única diferença que, em lugar de reflexão, põe o nome de meditação, e que em lugar de meditação se serve da palavra opinião.

É clara que essa razão é válida, pois é manifesto que a causa primeira está acima de todas as coisas sensíveis, imagináveis e corruptíveis; porém não é tão claro que a causa primeira esteja também acima de todas as coisas inteligíveis e sempiternas. Este autor omite esta prova que Proclo desenvolve e formula dizendo que todo conhecimento intelectual ou racional versa sobre os entes, pois o primeiro que é concebido pelo entendimento é o ente; enquanto que aquilo que não tem razão de ente não é suscetível de ser captado pelo entendimento. Portanto, existindo a causa primeira acima do ente, temos por consequência que a causa primeira também existe acima das coisas sempiternas.

Já dissemos que, segundo os platônicos, a causa primeira, enquanto é a essência da bondade e da unidade, está e existe acima do ente, e, portanto, é superior ao próprio ente separado. Porém, falando segundo a verdade das coisas, a causa primeira está sobre o ente ou é superior ao ente enquanto a própria causa primeira é o próprio ser infinito; e, portanto, guarda proporção com a capacidade de nosso entendimento ou está em nosso alcance. Pois o objeto do intelecto é o que a coisa é, segundo consta no livro III Sobre a Alma: portanto, somente aquilo que tem quididade participada do ser é capaz de ser entendido, e como a essência ou quididade de Deus é seu próprio ser (infinito), por isso mesmo está acima de nosso entendimento.

Dionísio aduz esta mesma razão no capítulo I Sobre os Nomes Divinos, formulando-a do seguinte modo: "Se todos os nossos conhecimentos versam sobre as coisas existentes, e se as coisas existentes têm fim ou termo (são finitas) enquanto participam de um modo finito do ser, Aquele que existe acima de toda substância está fora de alcance de qualquer outro conhecimento".

Em terceiro lugar, passa a expor como é conhecida a causa primeira e diz que a causa primeira só é expressa de algum modo por aquelas coisas que pertencem à segunda causa que é a 
inteligência, de sorte que falamos de Deus como se falássemos de certa substância inteligente, pois por ser a inteligência seu primeiro efeito, é o efeito mais parecido a Deus, e através do mesmo efeito se expressa o melhor modo de conhecê-lo. Porém, este conhecimento que se obtém através da inteligência é insuficiente, porque a inteligência está na primeira causa de um modo mais elevado, pois a causa supera o efeito; portanto não pode ser conhecida suficientemente a causa através de seu efeito. E assim fica demonstrado que a causa primeira é superior a tudo quanto alcance narrar a fala, porque não pode ser conhecida nem narrada suficientemente nem através da causa da primeira causa, nem em si mesma, nem através do efeito.

\section{Proposição XV, lição XV}

Como a alma conhece a si mesma

Todo cognoscente que conhece sua essência, volta à sua essência por reflexão completa. O que se explica pelo que a ciência não é senão uma ação intelectual. Quando, pois, um cognoscente conhece sua essência, volta-se, por sua operação inteligível, à sua essência. E isto se explica porque é uma só coisa o que conhece e a coisa conhecida, porque o conhecimento daquele que conhece sua essência provém dele e a ele volta, porque ele mesmo é a coisa conhecida. Ademais, isto significa que o conhecimento é ciência do cognoscente e que o cognoscente conhece a sua essência; ou seja, sua operação é regressiva à sua essência. Portanto, sua substância é regressiva à sua essência.

E não indico por regressão da substância à sua essência senão que a substância permanece fixa em si, não necessitando em sua permanência e sua essência de outra coisa que a sustente do que a mesma, porque é uma substância simples, suficiente por si e para si mesma.

\section{Comentário}

Depois de se expor como a alma se relaciona com as outras coisas, mostra-se aqui como ela se relaciona consigo mesma. E, assim, se propõe: todo cognoscente que conhece sua essência, volta à sua essência por reflexão completa. 
Para o entendimento desta proposição, devem-se considerar certas proposições expostas no livro de Proclo, uma das quais é a proposição que reza que tudo que é conversivo a si mesmo é incorpóreo. E esta proposição foi esclarecida acima na proposição VII deste livro.

A segunda proposição é a XVI do livro de Proclo e é tal: tudo que é conversivo a si mesmo tem a substância separada de todo corpo. A prova disso é que como o corpo não pode se converter a si mesmo, como decorreu da proposição anterior, segue-se que a conversão a si mesmo seja operação separada do corpo. Ora, como tal operação é separada do corpo, é necessário que a substância também o seja. Donde tudo que a si mesmo se pode converter é separável do corpo.

A terceira proposição, tomada da XLIII do livro, é esta: Tudo aquilo que é conversível em si mesmo é autohipóstaton, ou seja, subsistente por si mesmo. Isto é provado porque cada coisa se converte naquilo que a substancializa. Daí que, se se converte sobre si mesma segundo o seu ser, é necessário que subsista em si mesma.

A quarta proposição é tomada da proposição XLIV: tudo aquilo que segundo sua operação é a si mesmo conversível, é convertido a si mesmo segundo sua substância. Prova-se isto pelo seguinte argumento: a conversão a si mesmo implica perfeição. Ora, se aquilo que se converte consoante a operação não se convertesse segundo a substância, seguir-se-ia daí que a operação seria melhor e mais perfeita que a substância.

A quinta proposição é tomada da LXXXIII do livro: Todo aquele que conhece a si próprio é totalmente conversível a si mesmo. Cuja prova é que todo aquele que conhece a si próprio converte-se a si mesmo por sua operação, converte-se consequentemente por sua substância, como ficou patente pela proposição anterior.

A sexta proposição, CLXXXVI de Proclo, afirma que toda alma é substância incorpórea e separável do corpo. Assim pode ser provada: a alma conhece a si mesma; portanto, converte-se totalmente a si mesma; por conseguinte, é incorpórea e separável do corpo.

Expostas tais proposições, três asserções do autor nesse livro devem ser consideradas. A primeira diz que a alma conhece sua essência, pois o que é dito aqui deve ser entendido com relação à alma. Segundo, o que daí se conclui é que a alma volta à sua essência por reflexão completa. Isto é o mesmo que diz Proclo: tudo aquilo que é conhecedor de si mesmo é conversível totalmente a si mesmo e entende-se reflexão ou conversão completa segundo a substância e segundo a operação, como ficou patente. 
A segunda afirmação é demonstrada pela primeira e, assim, se argumenta: porque quando digo que o conhecedor conhece a sua essência, o próprio conhecer significa a operação inteligível. Portanto, fica patente que o conhecedor se converte naquilo pelo que conhece a sua essência, ou seja, é convertido pela sua operação inteligível à sua essência, entendendo-a. Que esta operação se deva chamar reflexão ou conversão manifesta-se pelo fato de que, quando a alma conhece a sua essência, o conhecedor e o conhecido são uma coisa. A ciência pela qual conhece a sua essência, isto é, a própria operação inteligível, deriva dela enquanto é conhecedora e é para ela enquanto é conhecida, e, assim, há aí certa circulação que é significada pelas palavras refletir e converter.

Daí que, depois de afirmar que a alma volta-se sobre sua essência segundo sua operação, conclui, em seguida, que também quanto à sua substância a alma volta-se sobre si mesma, de modo que realiza a reflexão completa segundo a operação e segundo a substância.

O autor expõe, em seguida, o que é voltar segundo a substância à sua essência. Diz-se que se voltam sobre si mesmas segundo a substância aquelas coisas que têm fixação de modo que não se voltam sobre outra coisa que as sustente tal como acontece na conversão dos acidentes à substância. E esta volta convém à alma e a qualquer coisa que se conheça a si mesma, porque tudo aquilo que é tal, é substância simples, suficiente a si e para si mesmo, não necessitando de nenhum substrato material. E esta pode ser a terceira proposição: que a alma seja separável do corpo, o que está claramente subentendido na proposição de Proclo.

A primeira das proposições, a saber, que a alma conhece a sua essência, o autor não a prova. Ela é, porém, é assim provada no livro de Proclo: é manifesto que a alma conheça a si mesma, pois, se a alma conhece as coisas que estão acima de si mesma, a fortiori pertence à sua natureza conhecer a si mesma, como conhecer a si mesma a partir das causas que são anteriores a si mesma. Donde se deve considerar cuidadosamente o que ficou dito a respeito do conhecimento dos intelectos, já que se afirmou que o Intelecto primeiro entende somente a si mesmo, como na proposição XIII ficou dito que o próprio é a forma inteligível ideal. Outros intelectos, enquanto lhe são próximos, participam do primeiro intelecto pela forma da inteligibilidade e pela virtude da intelectualidade conforme Dionísio no De Divinis Nominibus, capítulo IV, que defende que as supremas substâncias são inteligíveis e intelectuais. Donde cada um deles entende a si mesmo e o superior do qual participa.

Porém, porque a alma intelectiva participa de modo inferior do primeiro Intelecto, em sua substância não tem senão a força da intelectualidade. Donde entende a sua substância não pela 
sua essência, mas, segundo Platão, pelas coisas superiores do qual participa; e, segundo Aristóteles, no De Anima, III, pelas espécies inteligíveis, que são como formas, enquanto por elas é posta em ato.

\section{Proposição XXI, lição XXI}

Demonstração da suficiência do governo divino a partir de sua excelência

O Primeiro é rico por si mesmo e não há riqueza maior. E isso se deve à Sua unidade; não porque sua unidade seja esparsa, ao contrário, Ele é unidade pura, porque é simples e de simplicidade infinita.

Se alguém deseja conhecer a riqueza da Causa Primeira, lance sua mente sobre as coisas compostas, perscrutando sua natureza, e compreenderá que todo composto é mínimo, por necessitar seja de outro, seja daquilo que o compõe. Ao contrário, o simples, que é Bondade, é uno e Sua unidade é bondade e Sua bondade é una.

É, pois, mais rica a coisa que exerce seu influxo em outra do que a que recebe influxo de algo sobre si mesma. Assim, as outras coisas, inteligíveis ou corpóreas, não são ricas por si mesmas, ao contrário, necessitam do Uno-Verdadeiro que exerça seu influxo sobre sua bondade e sobre todas as suas graças.

\section{Comentário}

O autor, depois de ter assinalado de que modo o governo divino é exercido, passa agora a apresentar dois argumentos para provar que Deus é autossuficiente em seu governo. O primeiro parte da riqueza de Deus; o segundo, de sua excelência.

Duas perfeições são, pois, necessárias para o governo. A primeira é a abundância de bens com a qual possa prover os súditos. Por isso afirma Dionísio no c. XIII do De Divinis Nominibus: o domínio consiste na posse perfeita de todo bem e belo, e que o governo tem por fim a distribuição da lei e da ordem.

Prova que Deus é primeira e maximamente simples a partir de sua unidade: de fato Deus é perfeitamente uno na medida em que é Unidade e Bondade primeiras; e a simplicidade pertence à 
natureza da unidade. Pois simples é aquilo que, sem ser composto por outros, é uno. Assim Deus, na medida em que é primeiro e uno em grau máximo, é primeira e absolutamente simples.

A partir daí, prossegue demonstrando a segunda parte de sua proposição, ou seja, que Deus é em grau máximo autossuficiente, porque a autossuficiência procede da simplicidade. Pois todo composto necessita de vários componentes a partir dos quais se forma sua unidade. E não somente precisa desses componentes como partes suas, mas também de algo que cause e conserve sua composição, como é manifesto nos corpos mistos. Com efeito, as coisas diversas só chegam à unidade por alguma causa que as una. Em consequência, Deus sendo primeira e maximamente simples, por ter toda a sua bondade em unidade perfeitíssima, é por primeiro e em grau supremo autossuficiente.

Mas o autor do livro omite a primeira parte da proposição que trata da simplicidade, como que a supusesse, e trata somente da autossuficiência que chama de riqueza. E onde Proclo diz que Deus é autossuficiente afirma somente que é rico por si mesmo: pois é primeiro em qualquer gênero aquilo que é por si mesmo; de fato, aquilo que é por si é anterior àquilo que é por outro. E onde Proclo diz que Deus é suficiente de modo máximo, o nosso autor diz que é o mais rico, isto é, mais rico do que as outras coisas.

Entretanto, a prova da proposição é a mesma em ambos. Com efeito, quando se diz que a unidade divina, porque não está dispersa em muitas partes, mas é unidade pura, é o mesmo que dizer que Deus é simplicidade total, isto é, maximamente simples.

A partir disso, prova-se que Deus seja autossuficiente de modo supremo pela manifesta indigência dos compostos, como se disse anteriormente.

Porém, porque com o nome de riqueza não se entende apenas suficiência, mas também a copiosa potência que beneficia os outros, o nosso autor acrescenta, para demonstrar a riqueza de Deus, o influxo de sua bondade sobre as coisas: por sua bondade exerce seu influxo sobre as outras coisas, mas nada pode influenciá-lo. Em contrapartida, todas as outras coisas, sejam inteligíveis, como as Inteligências e as Almas, sejam corpóreas, não são ricas por si mesmas, como se tivessem abundância de bondade, mas precisam participar da bondade do Primeiro e verdadeiramente Uno, que influi sobre elas gratuitamente, sem que isso lhe acrescente algo a todas as suas bondades e perfeições. 


\section{Proposição XXXI, lição XXXI}

A ordem dos eternos entre si

Entre uma coisa, cuja substância e ação estão no momento da eternidade, e outra coisa, cuja substância e ação estão no momento do tempo, existe um intermediário: aquele cuja substância está no momento da eternidade e a operação no momento do tempo. O que se explica porque a coisa cuja substância está sujeita ao tempo na medida em que o tempo a contém, está sujeita ao tempo sobre todas as suas disposições; e, portanto, sua própria ação está sujeita ao tempo, já que está contida no tempo a substância da coisa, de modo que sua ação está sujeita ao tempo. Por outro lado, a coisa que sob todas as suas disposições está sujeita ao tempo não tem nenhuma conexão com a coisa que sob todas as suas disposições está sujeita à eternidade; pois a continuidade não se efetua a não ser entre coisas semelhantes. É necessário, por conseguinte, que exista uma terceira coisa, intermediária entre ambas, cuja substância sujeite-se à eternidade e à própria ação, ao tempo.

É impossível que exista uma coisa cuja substância esteja sujeita ao tempo e sua ação na eternidade, pela simples razão de que sua ação seria melhor do que sua própria substância - o que é impossível.

Portanto, é manifesto que entre as coisas sujeitas ao tempo com suas substâncias e suas ações e as coisas cujas substâncias e ações sujeitam-se a um momento da eternidade, existem outras coisas que por suas substâncias estão sujeitas à eternidade e por suas operações estão sujeitas ao tempo, com defendemos.

\section{Comentário}

$\mathrm{Na}$ proposição precedente ficou patente a ordem das coisas temporais entre si. Resta mostrar aqui a ordem das coisas eternas. Em primeiro lugar, põe-se entre as eternas o que é totalmente eterno e o que é em certa medida eterno e em outra, temporal. Em segundo lugar, expõe-se a condição daquilo que é eterno e temporal de algum modo, consoante a proposição XXXII, onde se diz "Toda substância" etc.

Acerca do primeiro, estabelece-se a seguinte proposição: Entre uma coisa, cuja substância e ação estão no momento da eternidade, e outra coisa, cuja substância e ação estão no momento 
do tempo, existe um intermediário: aquele cuja substância está no momento da eternidade e a operação no momento do tempo.

Parece que aqui se toma "momento da eternidade" por medida, de modo que quando se diz estar no momento da eternidade é como se se indicasse aquilo que pela eternidade é medido e no momento do tempo, o que pelo tempo é medido.

Esta proposição corresponde à CVI do livro de Proclo, que assim se exprime: Entre aquilo que é eterno segundo a substância e a operação e aquilo que tem a substância no tempo, existe um intermediário, e é aquilo que é eterno quanto à substância e cuja operação é medida pelo tempo.

Porém, poderia parecer a alguém que este intermediário fosse o corpo celeste, que é incorruptível quanto à sua substância, enquanto seu movimento é medido pelo tempo. Mas isso não procede. De fato, na proposição precedente ficou estabelecido que aquilo que sempre se move está absolutamente situado entre as coisas temporais, como já dizia o Filósofo no IV livro da Física: assim como o tempo mede o movimento, o movimento é a medida do que é móvel. Assim, o corpo celeste, que é movido, não está no momento da eternidade, mas no momento do tempo. Ademais, o movimento não é ação daquilo que é movido, mas sim, paixão. É ação do movente, como se diz no livro III da Física.

Entretanto, o princípio do movimento é a alma, como se sustentou na terceira proposição. A alma em si mesma é imóvel, sua ação, porém, é movimento. Segue-se daí que a alma, segundo sua substância, está no momento da eternidade, entretanto, sua ação está no tempo. A substância e a ação da inteligência, porém, estão no momento da eternidade.

A prova desta proposição é semelhante à prova da proposição anterior. De fato, disse-se acima que os graus dos entes continuam entre si consoante certa semelhança, donde aquelas coisas que são totalmente dessemelhantes seguem-se uma a outra a ordem das coisas por um intermediário que tem semelhante com um e outro dos extremos. Aquela coisa cuja substância e ação são no tempo é totalmente dessemelhante àquela cuja substância e ação acontecem na eternidade. Portanto, é necessário admitir entre elas um intermediário, ou seja, uma substância que caia sob a eternidade e cuja ação caia sob o tempo, e vice-versa.

Mas não pode acontecer que a substância de alguma coisa esteja no tempo e sua ação na eternidade, porque assim a ação seria mais alta e melhor do que a substância, e o efeito que a causa, o que é impossível. Logo, resta que aquele intermediário esteja quanto à substância no 
momento da eternidade; e, segundo a operação, no tempo. E isto era o que nos propusemos provar.

\section{Proposição XXXII, lição XXXII}

Sobre a condição intermediária da substância entre eternidade e o tempo

Toda substância que, por algumas de suas disposições, está sujeita à eternidade e, por outras, ao tempo, é simultaneamente ente e devir.

Toda coisa submetida à eternidade é verdadeiramente ente e toda coisa sujeita ao tempo é verdadeiramente um devir. Se portanto assim é, uma mesma coisa sujeita à eternidade e ao tempo, não o é sob mesmo aspecto, mas sim sob aspectos diferentes.

Por conseguinte, é manifesto que todo gerado que por sua substância está sujeito ao tempo possui uma substância dependente do puro ente, que é ao mesmo tempo causa da duração e de todas as coisas sempiternas e perecíveis.

É necessário que o Uno, que faz adquirir as unidades, não a tenha por aquisição, e que as restantes unidades sejam todas adquiridas. E o significado disso seria: se o Uno faz adquirir o nãoadquirido e outro faz adquirir o adquirido, então que diferença haveria entre este e o primeiro no fazer adquirir? Não é possível que sejam semelhantes entre si em todas as suas disposições e haja alguma diferença entre ambos. Se, pois, um é semelhante ao outro em todas as suas disposições, então um deles não seria o primeiro e o outro o segundo. De modo que, se um deles não é semelhante ao outro então, sem dúvida alguma, um deles é primeiro e outro, segundo. Portanto, aquele no qual a unidade é fixa não dependente de outro é o uno primeiro verdadeiro, consoante o exposto; e aquele em que a unidade advém de outro está fora do Primeiro Uno Verdadeiro. Portanto, se é de outro que obtém a unidade, é do primeiro uno que esta é obtida. Donde se explica que pertence ao puro verdadeiro uno e que os outros unos também têm unidade, mas não são unidade a não ser por causa do Uno Verdadeiro, que é causa da unidade.

Portanto, é claro e manifesto que toda unidade posterior ao uno-verdadeiro é adquirida; enquanto que o Uno-Verdadeiro puro cria as unidades fazendo adquirir o que Ele não tem como adquirido, como se demonstrou.

Comentário 
Porque na proposição precedente o autor demonstrou existir alguma coisa cuja substância está na eternidade e cuja ação está no tempo, ele defende consequentemente a condição de tal substância nesta última proposição: Toda substância que, sob certo aspecto, está submetida à eternidade, enquanto que em outro está sujeita ao tempo é simultaneamente ente e devir. Esta mesma proposição está na sentença CVII do livro de Proclo, nos seguintes termos: Tudo aquilo que por um lado é eterno e por outro é temporal é simultaneamente ente e devir.

Para clarificar tal proposição, o autor apresenta três argumentos: primeiramente, apresenta a prova de proposição aduzida, a qual depende totalmente do significado dos termos.

Porque, de fato, a eternidade é totalmente simultânea, carecedora de sucessão de passado e futuro, como se sustentou acima, por isso aquilo que existe na eternidade chama-se ente, porque está sempre em ato. O tempo, porém, consiste na sucessão de passado e futuro, donde aquilo que está no tempo está como in fieri: o que o termo geração ou devir. O que está totalmente na eternidade é totalmente ente; o que, entretanto, está totalmente no tempo é totalmente devir; o que está em um sentido na eternidade e em outro, no tempo, é simultaneamente ente e devir.

Em segundo lugar, onde diz: “De fato já está manifesto...” introduz certo corolário. Há, pois, certa disposição nos entes na qual os inferiores dependem dos superiores. Donde é necessário que aquilo que é totalmente devir, na medida em que tem sua substância e operação no tempo, dependa daquilo que é simultaneamente ente e devir, tendo sua substância na eternidade e sua ação no tempo. E também é necessário que este dependa daquilo que está totalmente na eternidade segundo sua substância e sua operação. E que este último dependa do Ente Primeiro que está acima da eternidade, que é o princípio da duração de todas as coisas, das sempiternas e das corruptíveis.

Em terceiro, onde se diz: "necessário é que o Uno..." defende-se que deste Uno primeiro todas as coisas dependem. Para se compreender o sentido de tal proposição, deve-se tomar a proposição CXVI de Proclo que é a que se segue: “Todo deus é participável, exceto o Uno”. Certamente esta proposição é introduzida pelo autor para mostrar como os platônicos admitiam vários deuses: não os punham, não obstante, no mesmo nível, mas o Uno era posto como primeiro, o qual de nada participava, mas era essencialmente Uno e Bom.

E o autor aduz seguinte prova: é manifesto que o Primeiro e Supremo Deus não participa de nada, do contrário, não seria a Causa primeira de todas as coisas; sempre, pois, o participante 
pressupõe um anterior, que é por essência. Mas que todos os outros deuses são participantes prova-se assim: se o primeiro Deus é uno essencialmente e não de modo participativo ou algum dos outros deuses é uno do mesmo modo e assim em nada difere do Primeiro ou é necessário que seja uno participativamente. Se, pois, o próprio Uno é essência do Primeiro, é necessário que se algo dele difere, como que existindo depois do Próprio, não seja tal que sua essência seja o próprio uno, mas participante da unidade.

E é isto que o autor propõe aqui: que é necessário admitir o primeiro Uno como o que provoca a unidade, isto é, que, por ele participam da unidade tudo que é uno, enquanto que Ele Próprio não a adquire, ou seja, nãoparticipa da unidade por algum outro. E cuja prova se aduz do precedente.

E assim termino o Livro Sobre as Causas. Graças sejam dadas ao Deus Onipotente, que é a Causa Primeira de todas as coisas. 